\title{
Salicylic acid in the physiological priming of onion seeds subjected to water and salt stresses
}

\author{
José E. S. B. da Silva ${ }^{1}$, Emanoela P. de Paiva ${ }^{2}$, Moadir de S. Leite ${ }^{2}$, Salvador B. Torres ${ }^{2}$, \\ Maria L. de Souza Neta² \& Keylan S. Guirra²
}

\begin{abstract}
${ }^{1}$ Instituto Federal de Ensino, Ciência e Tecnologia do Piauí/. Corrente, PI, Brasil. E-mail: jose.barbosa@ifpi.edu.br - ORCID: 0000-0003-3838-8672
${ }^{2}$ Universidade Federal Rural do Semi-Árido/Centro de Ciências Agrárias/Departamento de Ciências Agronômicas e Florestais. Mossoró, RN, Brasil. E-mail: emanuelappaiva@hotmail.com (Corresponding author) - ORCID: 0000-0003-4510-9205; moadir@outlook.com - ORCID: 0000-0003-0432-0522; sbtorres@ufersa.edu.br - ORCID: 0000-0003-0668-3327; lilia.agronomia@hotmail.com- ORCID: 0000-0002-2108-7526; ks_guirra@live.com - ORCID: 0000-0002-2510-6587
\end{abstract}

\begin{abstract}
This study aimed to evaluate the effect of physiological priming with salicylic acid on the mitigation of water and salt stresses on onion (Allium cepa L.) seeds. For this, seeds of onion, cultivar IPA 11 , were soaked in salicylic acid solution $(50 \mu \mathrm{M})$ for $24 \mathrm{~h}$ and placed to germinate at different water and saline potentials. For water stress, the experiment was conducted in a completely randomized design, in a $2 \times 5$ factorial scheme (salicylic acid with 0 and $50 \mu \mathrm{M}$ and osmotic potentials of $0,-0.1,-0.2,-0.3$, $-0.4 \mathrm{MPa}$ induced by polyethylene glycol 6000), with four repetitions of 50 seeds per plot. In salt stress, the adopted experimental design was completely randomized, with treatments distributed in a $2 \times 4$ factorial scheme (salicylic acid at concentrations of 0 and $50 \mu \mathrm{M}$ and the osmotic potentials of $0,-0.3,-0.6$ and $-0.9 \mathrm{MPa}$ induced by $\mathrm{NaCl}$ ), in four repetitions of 50 seeds. For both experiments, germination, growth and accumulation of organic solutes were evaluated. Salicylic acid did not stimulate the germination of onion seeds in the absence of stress, but the application of $50 \mu \mathrm{M}$ of salicylic acid increased the germination speed, growth and dry matter accumulation under conditions of water and salt stress. Onion plants were efficient in performing osmotic adjustment up to the potentials of $-0.2 \mathrm{MPa}$ induced by PEG 6000 under water stress and of $-0.4 \mathrm{MPa}$ induced by $\mathrm{NaCl}$ under salt stress.
\end{abstract}

Key words: Allium cepa, mitigator, water deficit, osmotic potential

\section{Ácido salicílico no condicionamento fisiológico de sementes de cebola submetidas a estresses hídrico e salino}

RESUMO: Objetivou-se avaliar o efeito do condicionamento fisiológico com ácido salicílico na mitigação dos estresses hídrico e salino em sementes de cebola (Allium cepa L.). Para isto, sementes de cebola, cultivar IPA 11, foram embebidas em solução de ácido salicílico $(50 \mu \mathrm{M})$ por $24 \mathrm{~h}$ e colocadas para germinar em diferentes potenciais hídricos e salinos. Para o estresse hídrico, o experimento foi conduzido em delineamento inteiramente casualizado, em esquema fatorial 2 x 5 (ácido salicílico com 0 e $50 \mu \mathrm{M}$ e potenciais osmóticos de $0 ;-0,1 ;-0,2 ;-0,3 ;-0,4 \mathrm{MPa}$ induzidos por polietilenoglicol 6000$)$, com quatro repetições de 50 sementes por parcela. No estresse salino, adotou-se o delineamento experimental inteiramente ao acaso, com os tratamentos distribuídos em esquema fatorial 2 x 4 (ácido salićlico nas concentrações de 0 e $50 \mu \mathrm{M}$ e os potenciais osmóticos de $0 ;-0,3 ;-0,6 ;-0,9 \mathrm{MPa}$ induzidos por $\mathrm{NaCl}$ ), em quatro repetições de 50 sementes. Para ambos os experimentos, avaliou-se a germinação, o crescimento e o acúmulo de solutos orgânicos. O ácido salicílico não estimulou a germinação de sementes de cebola na ausência de estresse, mas a aplicação de $50 \mu \mathrm{M}$ de ácido salicílico incrementou a velocidade de germinação, o crescimento e o acúmulo de matéria seca em condições de estresse hídrico e salino. As plantas de cebola foram eficientes em realizar ajustamento osmótico até os potenciais de -0,2 MPa induzidos por PEG 6000 no estresse hídrico, e de -0,4 MPa induzido por $\mathrm{NaCl}$ no estresse salino.

Palavras-chave: Allium cepa, mitigador, déficit hídrico, potencial osmótico 


\section{INTRODUCTION}

Onion (Allium cepa L.) is a vegetable crop with great economic importance and highly demanded by the consumer market. In Brazil, the average annual area cultivated with this species is 60 thousand hectares, with average consumption of seeds of $2.0 \mathrm{~kg} \mathrm{ha}^{-1}$, so the demand for this input is $120 \mathrm{t} \mathrm{year}^{-1}$ (Oliveira et al., 2014).

Onion is one of the most sensitive vegetables to water deficit, requiring adequate water availability in soil during its entire cycle (Marouelli et al., 2011). Since germination is one of the most critical stages of a plant's life cycle, water absorption is the main factor responsible for the beginning of the germinative process, being decisive in enzymatic reactions, solubilization and transport of metabolites (Marcos Filho, 2015).

The damage caused to plants by salt stress is related to osmotic stress and toxicity by specific ions, which modify their physiological and metabolic processes and, consequently, compromise germination and vegetative development (Carvalho \& Kazama, 2011). In this context, seed treatment aiming to improve germinative performance in response to abiotic stresses is feasible from the seed physiological quality point of view (Hayat et al., 2010; Umebese \& Bankole, 2013).

The use of exogenous or endogenous inducing substances such as organic acids (salicylic, ascorbic and citric) can improve the efficiency of metabolic processes or, also, directly act on metabolic pathways, which results in adaptation to abiotic stresses (Agostini et al., 2013). Salicylic acid is an endogenous growth regulator that participates in different physiological processes in plants (Hayat et al., 2010) and has shown ability to induce tolerance to abiotic stresses (Umebese \& Bankole, 2013).

Thus, the objective of this study was to evaluate the effect of physiological priming with salicylic acid on the mitigation of water and salt stresses on onion seeds.

\section{Material ANd Methods}

Two experiments were conducted in the Seed Analysis Laboratory of the Departamento de Ciências Vegetais da Universidade Federal Rural do Semiárido (UFERSA), Mossoró, RN, Brazil (located at 5 $11^{\prime} 16,8^{\prime \prime}, 37^{\circ} 20^{\prime} 38,4^{\prime \prime} \mathrm{W}$, with an altitude of 16 meters), using seeds of onion, cultivar IPA 11 . The seeds were placed in metallic package and stored in cold and dry chamber $\left(10 \pm 2{ }^{\circ} \mathrm{C}\right.$ and $50 \%$ air relative humidity) along the entire experimental period.

For the tests of water stress (experiment I) and salt stress (experiment II), onion seeds were placed in Gerbox boxes to soak for $24 \mathrm{~h}$ in $50 \mu \mathrm{M}$ salicylic acid solution and then placed in Biochemical Demand Oxygen (BOD) germination chambers, at $25^{\circ} \mathrm{C}$. The salicylic acid concentration of $50 \mu \mathrm{M}$ was determined based on preliminary tests of salicylic acid concentrations.

In experiment I, the seeds soaked in salicylic acid and not soaked (control) were sown under two sheets of blotting paper kept in transparent plastic boxes (Gerbox', $11 \times 11 \times 3.5 \mathrm{~cm}$ ) and placed in B.O.D.-type germination chambers, at $20^{\circ} \mathrm{C}$ and 12-h photoperiod (Brasil, 2009). The substrate was moistened with the equivalent to 2.5 times the paper weight using PEG6000 solutions, which were produced according to the values proposed by Villela et al. (1991) to simulate the previously established osmotic levels of $0,-0.1,-0.2,-0.3$ and $-0.4 \mathrm{MPa}$.

The experimental design was completely randomized, in a $2 \times 5$ factorial scheme (salicylic acid concentrations of 0 and $50 \mu \mathrm{M}$ and water potentials of $0,-0.1,-0.2,-0.3,-0.4 \mathrm{MPa}$ ), with four repetitions of 50 seeds per plot.

In experiment II, salt stress was simulated using sodium chloride $(\mathrm{NaCl})$ as solute, at the concentrations of $0,-0.3$, -0.6 and $-0.9 \mathrm{MPa}$ diluted in distilled water, and the electrical conductivity of the solutions was checked with a conductivity meter. For level zero (control), distilled water was used to moisten the substrate.

The experimental design was completely randomized, in a $2 \times 4$ factorial scheme (salicylic acid concentrations of 0 and $50 \mu \mathrm{M}$ and saline concentrations of $0,-0.3,-0.6$ and $-0.9 \mathrm{MPa}$ ), with four repetitions of 50 seeds per plot.

In both experiments, the germination test was monitored for 12 days, considering as normal the seedlings which produced perfectly developed primary root and shoots (Brasil, 2009). Along with this test, the germination speed index was determined, by daily evaluating the seedlings from the beginning of germination until twelve days, considering as germinated the seeds which produced 2-mm-long primary root, according to Maguire (1962).

At the end of the germination test, the normal onion seedlings of each treatment were evaluated for total length using a ruler graduated in millimeters, measured from the apex of the shoots to the tip of the primary root. Then, these seedlings were dried in a forced air circulation oven (65 ${ }^{\circ} \mathrm{C}$ ), until constant weight, and subsequently weighed on an analytical precision scale (0.001 g).

At the end of the experiments, samples of the shoot and root fresh masses of the seedlings were collected for the biochemical determinations (total soluble sugars and proline). The concentration of total soluble sugars was determined by the measurement of absorbance at $620 \mathrm{~nm}$, applying the anthrone method (Yemm \& Willis, 1954), using glucose as the standard substance. The results were expressed in $\mu \mathrm{mol} \mathrm{g}{ }^{-1}$ of fresh mass. Proline contents were determined following the methodology described by Bates et al. (1973), based on a standard curve obtained from L-proline by the measurement of absorbance at $520 \mathrm{~nm}$. The results were expressed in $\mu \mathrm{mol} \mathrm{g}^{-1}$ of fresh mass.

The data were subjected to analysis of variance by $\mathrm{F}$ test at $\mathrm{p} \leq 0.05$ and, according to the significance of regression analysis ( $\mathrm{p} \leq 0.05$ ) using the statistical program Sisvar" (Ferreira, 2011).

\section{Results AND Discussion}

\section{Experiment I}

The interaction between factors (osmotic potential $\mathrm{x}$ salicylic acid doses) had a significant effect $(p \leq 0.01)$ on germination speed index, total length and total dry mass of seedlings. For germination, there were separate significant effects of the two factors at $\mathrm{p} \leq 0.01$ and $\mathrm{p} \leq 0.05$, respectively. For the variables proline and total soluble sugars, there was a single effect of the osmotic potential at $\leq 0.01$ (Table 1 ). 
Table 1. Summary of analysis of variance for the variables germination percentage (GP), germination speed index (GSI), total length of seedlings (TLS), total dry mass (TDM), proline and total soluble sugars (TSS) of onion (Allium cepa L.) seeds primed at salicylic acid doses and subjected to different osmotic potentials

\begin{tabular}{|c|c|c|c|c|c|c|c|}
\hline \multirow{2}{*}{$\begin{array}{l}\text { Sources } \\
\text { of variation }\end{array}$} & \multirow{2}{*}{$\begin{array}{l}\text { Degrees } \\
\text { of freedom }\end{array}$} & \multicolumn{6}{|c|}{$\mathrm{Pr}>\mathrm{Fe}$} \\
\hline & & GP & GSI & TLS & TDM & Proline & TSS \\
\hline Potentials (P) & 4 & $0.000 * *$ & 0.000 ** & $0.000^{* \star}$ & $0.000^{\star \star}$ & $0.000 * \star$ & $0.000 * *$ \\
\hline Doses (D) & 1 & $0.037^{*}$ & 0.000 ** & $0.023^{\star *}$ & $0.161^{\mathrm{ns}}$ & $0.437^{\text {ns }}$ & $0.350^{\mathrm{ns}}$ \\
\hline$P \times D$ & 4 & $0.298^{\mathrm{ns}}$ & $0.003^{\star *}$ & $0.005^{\star \star}$ & $0.003^{* *}$ & $0.394^{\mathrm{ns}}$ & $0.431^{\mathrm{ns}}$ \\
\hline Error & 30 & -- & -- & -- & -- & -- & -- \\
\hline \multicolumn{2}{|c|}{ Coefficient of variation (\%) } & 9.38 & 6.07 & 13.28 & 10.95 & 16.20 & 9.11 \\
\hline
\end{tabular}

${ }^{*},{ }^{* *}$ and ${ }^{\mathrm{ns}}$ - Significant at $\mathrm{p} \leq 0.05, \mathrm{p} \leq 0.01$ and not significant, respectively

The percentage of germination of onion seeds was individually influenced by the osmotic potentials and doses of salicylic acid (Figures 1A and B). As a function of the reduction in the osmotic potential, germination decreased quadratically by $52 \%$, from- $0.07 \mathrm{MPa}$ to $-0.4 \mathrm{MPa}$ (Figure $1 \mathrm{~A}$ ). As for the doses of salicylic acid, there was a 6 percentual points reduction in the germination of seeds treated with $50 \mu \mathrm{M}$ of salicylic acid when compared to those of the control (Figure 1B).
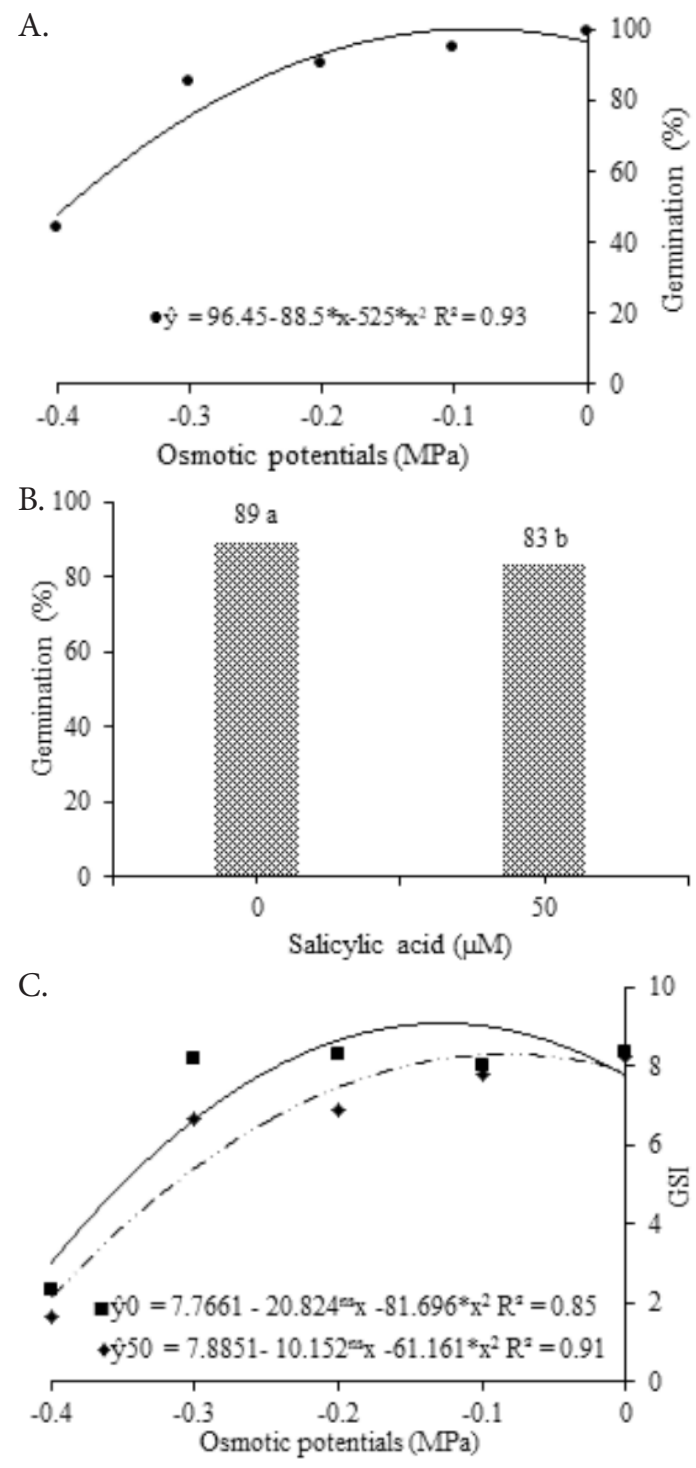

${ }^{n s}$ and * - Not significant and significant at $\mathrm{p} \leq 0.05$ by F test, respectively

Figure 1. Germination (A and B) and germination speed index - GSI (C) of onion (Allium cepa L.) seeds primed at doses of salicylic acid $(\cdot=0$ and $\bullet=50 \mu \mathrm{M})$ and subjected to different osmotic potentials
The interaction between osmotic potential levels and salicylic acid doses caused an effect on the germination speed index (Figure 1C). The germination speed index showed a quadratic behavior at both doses of salicylic acid studied, and highest values were found at the estimated values of -0.13 and $-0.08 \mathrm{MPa}$, for the salicylic acid doses of 0 and $50 \mu \mathrm{M}$, respectively. It is important to emphasize that the germination speed index of seeds treated with $50 \mu \mathrm{M}$ of salicylic acid was lower than that of the control under all water stress conditions. Although according to Vlot et al. (2009) salicylic acid regulates several processes such as cell growth, germination, seedling development and thermotolerance, in the present study there was no effect on the germination and vigor of onion seeds. Possibly, the salicylic acid dose of $50 \mu \mathrm{M}$ is above the ideal concentration to promote the attenuation of water stress on seed germination.

This reduction in germination, as the osmotic potentials become more negative, is explained by the water restriction, which decreases the velocity of the metabolic and biochemical processes, slowing or reducing seed germination percentage, interfering in the imbibition and in embryo cell elongation (Carvalho \& Nakagawa, 2012). The reduction of germination due to the increase in water deficit was also verified in melon seeds by Pinheiro et al. (2017), who observed germination close to $50 \%$ at the potential of $-0.4 \mathrm{MPa}$. By contrast, chia and sesame seeds do not tolerate osmotic potentials lower than -0.15 and $-0.2 \mathrm{MPa}$, respectively (Medeiros et al., 2015; Stefanello et al., 2017).

For the total length and total dry mass of onion seedlings, there was a significant influence of the interaction between osmotic potential levels and doses of salicylic acid (Figures $2 \mathrm{~A}$ and $\mathrm{B})$. At both doses of salicylic acid, there were linear reductions of 75.66 and $78.33 \%$ in length and 78.90 and $74.53 \%$ dry mass, respectively, when comparing the data of the control $(0 \mathrm{MPa})$ to those of $-0.4 \mathrm{MPa}$ (Figures $2 \mathrm{~A}$ and B). However, the treatment of onion seeds with $50 \mu \mathrm{M}$ of salicylic acid led to the highest lengths and the greatest dry mass accumulation at all osmotic potentials studied.

According to Kadioglu et al. (2011), salicylic acid acts as a signaler in the modulation of responses to environmental stresses. Silva et al. (2017), evaluating the influence of salicylic acid on sesame germination under water stress, found that the use of $10 \mu \mathrm{M}$ in seed treatment promoted greater tolerance during the initial development under water stress conditions, due to the action of the acid on the antioxidant system of the tissues.

Similarly, in barley plants, Habibi (2012) found that the application of $500 \mu \mathrm{M}$ of salicylic acid mitigated the effects of water stress. However, in watermelon seeds, salicylic acid 
A.
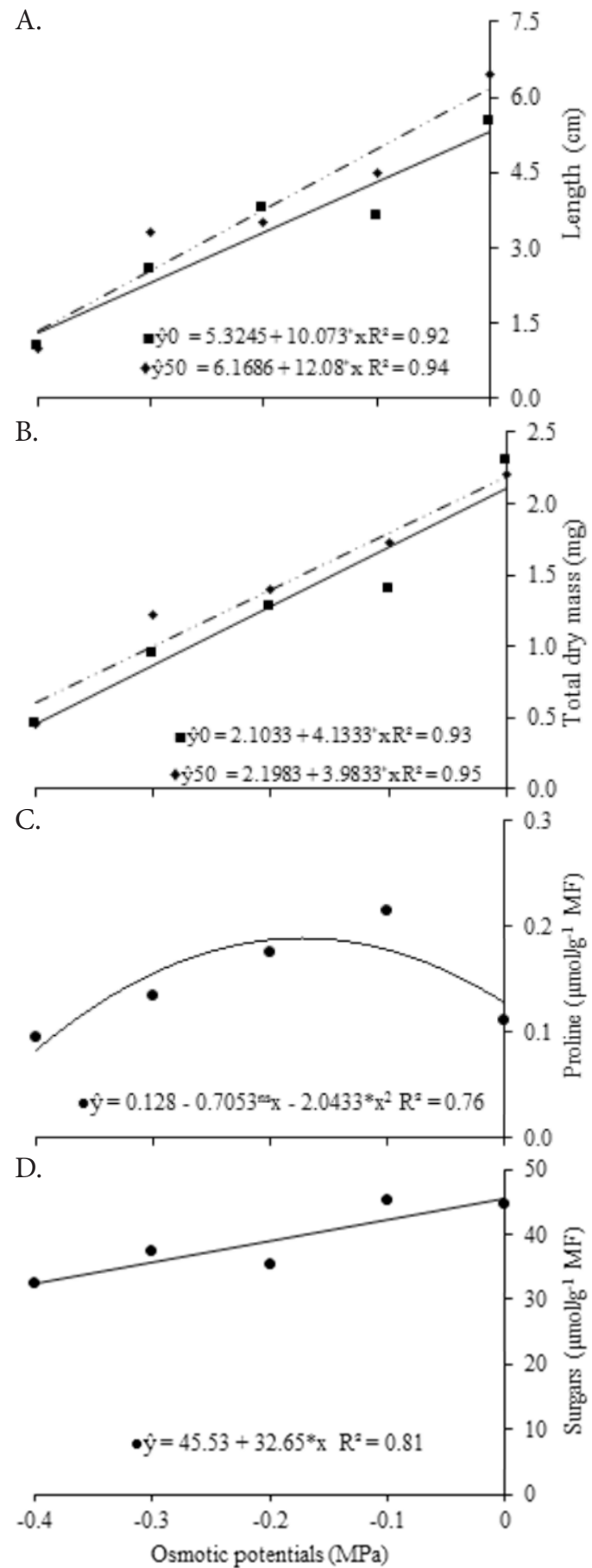

ns and ${ }^{*}$ - Not significant and significant at $\mathrm{p} \leq 0.05$ by F test, respectively FM - Fresh matter

Figure 2. Length (A), total dry mass (B), proline content (C) and total soluble sugars (D) of onion (Allium cepa L.) seedlings primed at doses of salicylic acid $(\boldsymbol{\bullet}=0$ and $\bullet=50$ $\mu \mathrm{M}$ ) and subjected to different osmotic potentials hampered germination, increasing germination time and seedling growth (Silva et al., 2014).

For proline accumulation, there was a single effect of the osmotic potential, and a quadratic behavior was observed as a function of the reduction in the osmotic potential, with increment in proline concentration up to $-0.17 \mathrm{MPa}$ and a reduction from this level to $-0.4 \mathrm{MPa}$ (Figure 2C). Sugar accumulation was only affected by the osmotic potential levels, but decreased linearly as a function of the reduction of osmotic potential, with a reduction of $29 \%$ between the control (0 MPa) and the potential of $-0.4 \mathrm{MPa}$ (Figure 2D).

Given the results, it is possible to state that onion seedlings have the accumulation of proline as a mechanism of tolerance to water stress, and this compound is used for osmotic adjustment and defense against water loss, maintaining the water potential in the leaf (Sousa et al., 2015). However, the accumulation of soluble sugars did not stand out as an effective mechanism in mitigating the effects of water stress on onion seedlings.

The results of this study demonstrate that onion seeds have the ability to perform osmotic adjustment under conditions of up to $-0.2 \mathrm{MPa}$. However, with the increase of water stress, the seeds do not exhibit the same capacity. Thus, it can be verified that, under conditions of low water availability, there is a reduction in the initial development of onion seedlings, likely due to metabolic damage to tissues and increased respiration. The metabolic changes include peroxidases, protein denaturation and increase in the levels of amino acids, especially proline (Sousa et al., 2015).

\section{Experiment II}

There was a significant effect $(p \leq 0.05)$ of the interaction on the variables germination speed index and total length of seedlings. For the variables germination, total dry mass, proline and total soluble sugars, there was single effect of the osmotic potentials at $\mathrm{p} \leq 0.01$ (Table 2).

The percentage of germination of onion seeds was influenced by the levels of osmotic potential, evidenced by its quadratic behavior as a function of the reduction of osmotic potential. Germination percentage decreased from the level of -0.17 to $-0.9 \mathrm{MPa}$, a reduction of $36 \%$ (Figure $3 \mathrm{~A}$ ).

For the germination speed index, there was an interaction between osmotic potential levels and salicylic acid doses, with a quadratic regression for this variable at both doses of salicylic acid. The highest germination speed indices were obtained at the estimated values of -0.19 and $-0.28 \mathrm{MPa}$ for the salicylic acid doses of 0 and $50 \mu \mathrm{M}$, respectively (Figure 3B). It is important to point out that the GSI of seeds treated with $50 \mu \mathrm{M}$ of salicylic acid was higher than that of the control

Table 2. Summary of analysis of variance for the variables germination percentage (GP), germination speed index (GSI), total length of seedlings (TLS), total dry mass (TDM), proline and total soluble sugars (TSS) of onion (Allium cepa L.) seeds primed at doses of salicylic acid and subjected to different osmotic potentials

\begin{tabular}{|c|c|c|c|c|c|c|c|}
\hline \multirow{2}{*}{$\begin{array}{c}\text { Sources } \\
\text { of variation }\end{array}$} & \multirow{2}{*}{$\begin{array}{l}\text { Degrees } \\
\text { of freedom }\end{array}$} & \multicolumn{6}{|c|}{$\mathrm{Pr}>\mathrm{Fe}$} \\
\hline & & GP (\%) & GSI & TLS & TDM & Proline & TSS \\
\hline Potentials (P) & 4 & $0.000^{* *}$ & $0.000^{* *}$ & $0.000^{* *}$ & $0.000^{* *}$ & $0.000^{* *}$ & $0.005^{* *}$ \\
\hline Doses (D) & 1 & $0.532^{\text {ns }}$ & $0.115^{\mathrm{ns}}$ & $0.358^{\text {ns }}$ & $0.750^{\mathrm{ns}}$ & $0.375^{\mathrm{ns}}$ & $0.315^{\mathrm{ns}}$ \\
\hline$P \times D$ & 4 & $0.781^{\mathrm{ns}}$ & $0.040^{\star}$ & $0.041^{\star}$ & $0.328^{\mathrm{ns}}$ & $0.139^{\text {ns }}$ & $0.213^{\mathrm{ns}}$ \\
\hline Error & 30 & -- & -- & -- & -- & -- & \\
\hline \multicolumn{2}{|c|}{ Coefficient of variation (\%) } & 14.22 & 11.54 & 20.49 & 10.95 & 7.72 & 3.82 \\
\hline
\end{tabular}

", " and ${ }^{\text {ns }}$ - Significant at $\mathrm{p} \leq 0.01, \mathrm{p} \leq 0.05$ ) and not significant, respectively, by $\mathrm{F}$ test 
A.
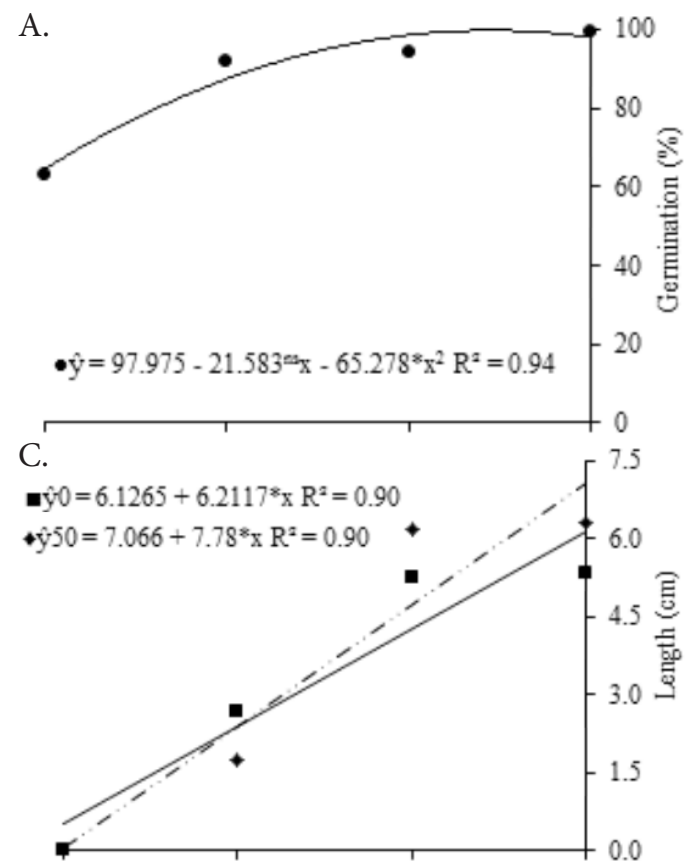

E.

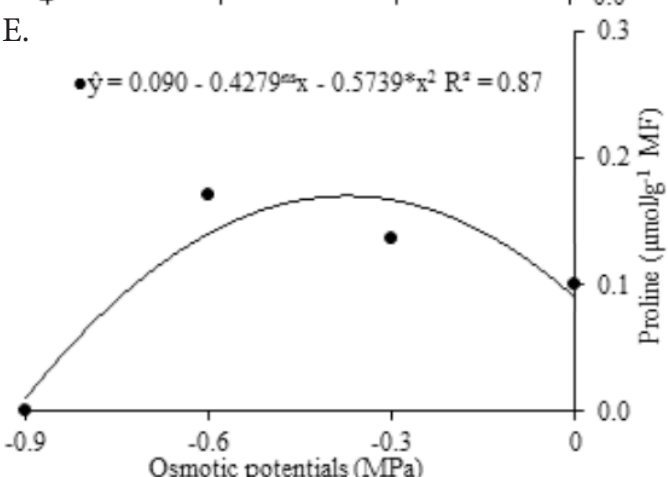

B.

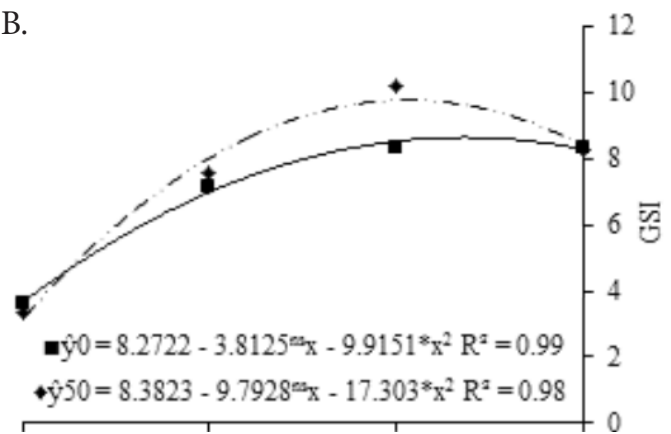

D.
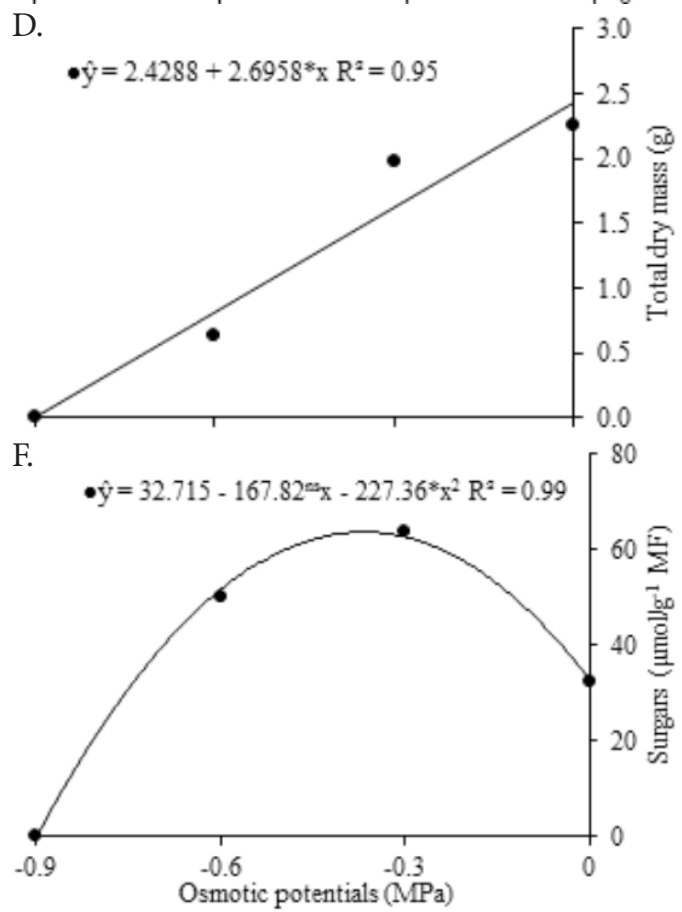

ns and ${ }^{*}$ - Not significant and significant at $\mathrm{p} \leq 0.05$ by F test, respectively

FM - Fresh matter

Figure 3. Germination (A), germination speed index, GSI (B), length (C), total dry mass (D), proline concentration (E) and total soluble sugars (F) of onion (Allium cepa L.) seedlings primed at doses of salicylic acid $(\cdot=0$ and $\bullet=50 \mu \mathrm{M})$ and subjected to different osmotic potentials induced by $\mathrm{NaCl}$

at all osmotic potentials evaluated. This result indicates that the attenuator accelerated the germinative process under salt stress conditions.

Salicylic acid is known for inducing responses related to the antioxidant system, which protects plants from damage caused by biotic or abiotic stresses, such as heat, cold and salt stress (Umebese \& Bankole, 2013). In species such as maize and wheat, Agami (2013) verified that salicylic acid induced increase in the tolerance to salinity and osmotic stress.

The length of onion seedlings was also affected by the interaction between osmotic potential levels and salicylic acid doses (Figure 3C). At both doses of salicylic acid, plant growth showed a decreasing linear behavior as a function of the increase in the osmotic potential induced by $\mathrm{NaCl}$. However, the seedlings of the treatment with $50 \mu \mathrm{M}$ of salicylic acid obtained higher growth than the control treatment up to the level of -0.6 MPa (Figure 3C). Corrêa et al. (2014) observed higher growth of onion seedlings at $120 \mathrm{mM}$ of $\mathrm{NaCl}$ treated with salicylic acid in comparison to the control, indicating the potential of this hormone for protection.

In contrast to seedling growth, salicylic acid did not influence the total dry mass of seedlings. For this variable, only the osmotic potential caused significant effect, with drastic reduction of phytomass accumulation as a function of the reduction in the osmotic potential induced by $\mathrm{NaCl}$. Death of seedlings was observed at the potential of $-0.9 \mathrm{MPa}$ (Figure $3 \mathrm{D})$. The inhibition of growth and phytomass accumulation in the presence of salinity is related to the ionic toxicity caused by salts in the metabolic processes of the cells, preventing or reducing plant growth (Bernardes et al., 2015).

For the concentration of proline and soluble sugars, there was single effect of the osmotic potential, with a quadratic behavior as a function of the reduction in the osmotic potential for both variables (Figures $3 \mathrm{E}$ and $\mathrm{F}$ ). The concentration of proline and soluble sugars increased up to $-0.37 \mathrm{MPa}$; however, from this value, there was a reduction in contents of proline and sugars up to $-0.9 \mathrm{MPa}$ (Figures $3 \mathrm{E}$ and $\mathrm{F}$ ). These results indicate that onion seedlings have the ability to perform osmotic adjustment under salt stress conditions of up to $-0.37 \mathrm{MPa}$.

\section{Conchusions}

1. Salicylic acid did not stimulate the germination of onion seeds in the absence of stress, but the application of $50 \mu \mathrm{M}$ of 
salicylic acid increased germination speed, growth and dry mass accumulation under conditions of water and salt stress.

2. Onion plants were efficient in performing osmotic adjustment up to the potentials of -0.2 MPa induced by PEG 6000 under water stress and up to $-0.4 \mathrm{MPa}$ induced by $\mathrm{NaCl}$ under salt stress.

3. Salicylic acid at $50 \mu \mathrm{M}$ concentration did not promote the accumulation of proline and soluble sugar in onion seeds.

\section{Literature Cited}

Agami, R. A. Alleviating the adverse effects of $\mathrm{NaCl}$ stress in maize seedlings by pretreating seeds with salicylic acid and 24-epibrassinolide. South African Journal of Botany, v.88, p.171177, 2013. https://doi.org/10.1016/j.sajb.2013.07.019

Agostini, E. A. T.; Machado Neto, N. B.; Custódio, C. C. Induction of water deficit tolerance by cold shock and salicylic acid during germination in the common bean. Acta Scientiarum. Agronomy, v.35, p.209-219, 2013. https://doi.org/10.4025/actasciagron. v35i2.15967

Bates, L. S.; Waldren, R. P.; Teare, I. D. Rapid determination of free proline for water-stress studies. Plant and Soil, v.39, p.205-207, 1973. https://doi.org/10.1007/BF00018060

Bernardes, P. M.; Mengarda, L. H. G.; Lopes, J. C.; Nogueira, M. U.; Rodrigues, L. L. Qualidade fisiológica de sementes de repolho de alta e baixa viabilidade sob estresse salino. Nucleus, v.12, p.7786, 2015. https://doi.org/10.3738/1982.2278.1105

Brasil. Ministério da Agricultura, Pecuária e Abastecimento. Regras para análise de sementes. Brasília: MAPA/ACS, 2009. 399p.

Carvalho, L. C.; Kazama, E. H. Efeito da salinidade de cloreto de potássio $(\mathrm{KCl})$ na germinação de sementes e crescimento de plântulas de pepino (Cucumis sativus L.). Enciclopédia Biosfera, v.7, p.429-435. 2011.

Carvalho, N. M.; Nakagawa, J. Sementes: Ciência, tecnologia e produção. 5.ed. Jaboticabal: FUNEP, 2012. 588p.

Corrêa, N. S.; Larré, C. F.; Moraes, C. L.; Tonel, F. R.; Argenta, J. C.; Moraes, D. M. Efeito do ácido salicílico na viabilidade e vigor de sementes de cebola sob estresse salino. Revista Congrega Urcamp, v.10, p.230-241, 2014.

Ferreira, D. F. Sisvar: A computer statistical analysis system. Ciência e Agrotecnologia, v.35, p.1039-1042, 2011. https://doi. org/10.1590/S1413-70542011000600001

Habibi, G. Exogenous salicylic acid alleviates oxidative damage of barley plants under drought stress. Acta Biologica Szegediensis, v.56, p.57-63, 2012.

Hayat, Q.; Hayat, S.; Irfan, M.; Ahmad, A. Effect of exogenous salicylic acid under changing environment: A review. Environmental and Experimental Botany, v.68, p.14-25, 2010. https://doi.org/10.1016/j.envexpbot.2009.08.005

Kadioglu, A.; Saruhan, N.; Sağlam, A.; Terzi, R.; Acet, T. Exogenous salicylic acid alleviates effects of long term drought stress and delays leaf rolling by inducing antioxidant system. Plant Growth Regulation, v.64, p.27-37, 2011. https://doi.org/10.1007/s10725010-9532-3
Maguire, J. D. Speed of germination-aid in selection and evaluation for seedling emergence and vigor. Crop Science, v.2, p.176-177, 1962. https://doi.org/10.2135/cropsci1962.0011183X000200020033x

Marcos Filho, J. Fisiologia de sementes de plantas cultivadas. 2.ed. Londrina: Abrates, 2015. 660p.

Marouelli, W. A.; Vidigal, S. M.; Costa, E. L. Irrigação e fertirrigação na cultura da cebola. In: Sousa, V. F.; Marouelli, W. A.; Coelho, E. F.; Pinto, J. M.; Coelho Filho, M. A. (ed.). Irrigação e fertirrigação em fruteiras e hortaliças. Brasília: Embrapa Informação Tecnológica, 2011. Cap.1, p.585-608.

Medeiros, D. S.; Alves, E. U.; Sena, D. V. A.; Silva, E. O.; Araújo, L. R. Desempenho fisiológico de sementes de gergelim submetidas a estresse hídrico em diferentes temperaturas. Semina: Ciências Agrárias, v.36, p.3069-3076, 2015. https://doi.org/10.5433/16790359.2015v36n5p3069

Oliveira, V. R.; Leite, D. L.; Santos, C. A. F.; Costa, N. D.; Melo, P. C. T. Produção de sementes de cebola. In: Nascimento, W. M. Produção de sementes de hortaliças. 1.ed. Brasília: Embrapa Informação Tecnológica, 2014. Cap.1, p.77-114.

Pinheiro, D. T.; Dias, D. C. F. S.; Araújo, J. O. Germination of melon seeds under water and thermal stress. Journal of Seed Science, v.39, p.440-447, 2017. https://doi.org/10.1590/2317-1545v39n4188530

Silva, A. C.; Suassuna, J. F.; Melo, A. S.; Costa, R. R.; Andrade, W. A.; Silva, D. C. Salicylic acid as attenuator of drought stress on germination and initial development of sesame. Revista Brasileira de Engenharia Agrícola e Ambiental, v.21, p.156-162, 2017. https://doi.org/10.1590/1807-1929/agriambi.v21n3p156-162

Silva, T. C. F. S.; Silva, R. C. B.; Silva, J. E. S. B.; Santos, R. S.; Aragão, C. A.; Dantas, B. F. Germinação de sementes de melancia sob diferentes métodos de tratamento com reguladores vegetais. Scientia Plena, v.10, p. 1-15, 2014.

Sousa, C. C. M.; Pedrosa, E. M. R.; Rolim, M. M.; Oliveira Filho, R. A.; Souza, M. A. L. M.; Pereira Filho, J. V. Crescimento e respostas enzimáticas do feijoeiro caupi sob estresse hídrico e nematoide de galhas. Revista Brasileira de Engenharia Agrícola e Ambiental, v.19, p.113-118, 2015. https://doi.org/10.1590/18071929/agriambi.v19n2p113-118

Stefanello, R.; Viana, B. B.; Neves, L. A. S. Resposta fisiológica de sementes de chia e linhaça ao estresse hídrico. Iheringia, v.72, p.161-163, 2017. https://doi.org/10.21826/2446-8231201772202

Umebese, C. E.; Bankole, A. E. Impact of salicylic acid on antioxidants, biomass and osmotic adjustments in Vigna unguiculata L. Walp. during water deficit stress. African Journal of Biotechnology, v.12, p.5200-5207, 2013. https://doi.org/10.5897/AJB2013.12087

Villela, F. A.; Doni Filho, L.; Sequeira, E. L. Tabela de potencial osmótico em função da concentração de polietilenoglicol 6000 e da temperatura. Pesquisa Agropecuária Brasileira, v.26, p.19571968, 1991.

Vlot, A. C.; Dempsey, D. A.; Klessig, D. F. Salicylic acid a multifaceted hormone to combat disease. Annual Review Phytopathology, v.47, p.177-206, 2009. https://doi.org/10.1146/ annurev.phyto.050908.135202

Yemm, E. W.; Willis, A. J. The estimation of carbohydrates in plant extracts by anthrone. Biochemical Journal, v.57, p.508-514, 1954. 